\title{
Biosaline production of seedlings of native species from the Caatinga dry forest
}

\author{
Produção biossalina de mudas de espécies florestais nativas da Caatinga
}

\section{Barbara França Dantas ${ }^{\mathrm{I}}$, Renata Conduru Ribeiro"I , Gilmara Moreira de Oliveira ${ }^{\mathrm{III}}$, Fabrício Francisco Santos da Silva $^{\mathrm{IV}}$, Gherman Garcia Leal de Araújo ${ }^{\mathrm{v}}$}

\begin{abstract}
The Caatinga dry forest species are well adapted and resilient to the climatic conditions of the Brazilian semiarid region. However, this is one of the more vulnerable ecosystems to climate change, due to increasing deforestation and drought in the last years. Water shortage in this region has prompted studies into the possibility of safe brackish water use/reuse for forage and forest seedling production. We tested, in this study, alternative sources to potable water to irrigate forest seedlings in nurseries, which have high water expenditure. The trail was performed in a completely randomized design with three irrigation water sources and four replications with five seedlings. Biosaline fish cropping water; brackish groundwater and tap water were used for irrigation of seedlings of Anadenanthera colubrina, Erythrina velutina and Aspidosperma pyrifolium, grown in a screened nursery greenhouse in polyethylene bags filled with sand and soil $(1: 1 \mathrm{v} / \mathrm{v})$. Seed germination and seedlings growth were evaluated for up to 80 days. Results showed that irrigation with biosaline fish farming waste water with electrical conductivity values $>6 \mathrm{dS} . \mathrm{m}^{-1} \mathrm{did}$ not compromise the seed germination nor the seedlings growth in nursery. Brackish ground water, however, slowed the development of seedlings. Faced with the possibility of water shortages due to climate change, the use of non-potable sources of water, can therefore, be an alternative and low input technique for the production of seedlings of native species from Caatinga.
\end{abstract}

Keywords: Brackish water; Seedling production; Irrigation; Nursery

\section{Resumo}

As espécies florestais da Caatinga estão adaptadas e são resilientes às condições climáticas da região semiárida brasileira. No entanto, este é um dos ecossistemas mais vulneráveis às mudanças climáticas, devido ao aumento do desmatamento e à seca dos últimos anos. A escassez de água nessa região induziu estudos sobre a possibilidade de utilização/reutilização segura da água salobra para a produção de forragem e de mudas florestais. Testaram-se, nesse estudo, fontes alternativas à água potável para irrigação de mudas florestais em viveiros, que apresentam elevado gasto de água. O ensaio foi realizado em delineamento inteiramente casualizado com três fontes de água para irrigação e quatro repetições de cinco plântulas. Água biossalina, provinda de cultivo de peixe; água subterrânea salobra e água de abastecimento foram utilizadas para irrigar mudas de Anadenanthera colubrina, Erythrina velutina e Aspidosperma pyrifolium, cultivadas em viveiro telado em embalagens de polietileno preenchidas com areia e solo $(1: 1, \mathrm{v} / \mathrm{v})$. A porcentagem de germinação das sementes e o crescimento das mudas foram avaliados até 80 dias. Os resultados mostraram que a irrigação com água biossalina residual de piscicultura, com valores de condutividade elétrica $<6 \mathrm{dS} \cdot \mathrm{m}^{-1}$ não comprometeu a germinação das sementes, nem o crescimento de mudas em viveiro. A água salobra subterrânea reduziu a velocidade de desenvolvimento das mudas. Diante a possibilidade de escassez de água devido às mudanças do clima, o uso de fontes não potáveis de água pode, portanto, ser uma técnica alternativa de baixo custo, para a produção de mudas de espécies da Caatinga.

Palavras-chave: Água salobra; Produção de mudas; Irrigação; Viveiro

I Engenheira Agrônoma, Dr., Pesquisadora, Embrapa Semiárido, Rod. BR-428, Km 152, Zona Rural, Caixa Postal 23, CEP 56302-970, Petrolina (PE), Brasil. barbara.dantas@embrapa.br (ORCID: 0000-0002-2375-9373)

Bióloga, Dr., Pesquisadora autônoma, Embrapa Semiárido, Rod. BR-428, Km 152, Zona Rural, Caixa Postal 23, CEP 56302-970, Petrolina (PE), Brasil.rconduru@gmail.com (ORCID: 0000-0001-8912-2634)

III Engenheira Agrônoma, Dr., Universidade Estadual de Feira de Santana, Av. Transnordestina, s/n, Novo Horizonte, CEP 44036-900, Feira de Santana, Bahia (BA), Brasil. gilmara_5@hotmail.com (ORCID: 0000-0002-2051-0193)

Biólogo, Dr., Professor da Universidade Federal do Vale do São Francisco, Campus Ciências Agrárias, Rod. BR 407, Km 119, CEP 56300-990, Petrolina (PE), Brasil. fabriciofrancisco2006@gmail.com (ORCID: 0000-0001-7938-8308)

Zootecnista, Dr., Pesquisador, Embrapa Semiárido, Rod. BR-428, Km 152, Zona Rural, Caixa Postal 23, CEP 56302-970, Petrolina (PE), Brasil. (ORCID: 0000-0001-9605-1096) 


\section{Introduction}

The tropical dry forests, such as Caatinga, are the most threatened fragile and sensitive to strong interactions between human activities and climate changes (MILES et al., 2006) and considered the most endangered tropical forests (JANZEN, 1988). This is due to climatic conditions, soil characteristics, and anthropogenic impact. Its vegetation covers the Brazilian semiarid region, with a territorial extension of approximately $800 \mathrm{~km}^{2}$, and it constitutes about $80 \%$ of the Northeast Region of Brazil and $11 \%$ of Brazilian national territory (SANTOS et al., 2012). Since 2010, this region has been facing the worst prolonged drought of the last 100 years, with devastating effects on vegetation (GUTIÉRREZ et al., 2014). In these semiarid environments water is an utterly important natural resource, especially due to its role in agricultural development.

The global impact of deforestation driven largely by agricultural expansion is a major component of ongoing global environmental change that contributes significantly to atmospheric greenhouse gas accumulation and climate change (ZOMER et al., 2008), which, in turn, will contribute for the decrease of fresh water available and thus an aridization of the environment (MARENGO, 2014; SALAZAR; NOBRE; OYAMA, 2007). Unfortunately, the amount of land affected by salinity alone or combined with other stresses and the amount of brackish groundwater in semiarid areas is expected to increase in the near future according to the estimations for the global climate change (IPCC, 2013). At the same time, almost 500.000 ha of Caatinga vegetation are deforested per year and are predicted to decrease by aridization (SALAZAR; NOBRE; OYAMA, 2007). The scarcity of rainfall and the lack of a development policy that takes into account regional specificities compromises the quality of life in the Caatinga domain. In this context, it is necessary to preserve the best quality freshwater for human supply, as well as to seek the use of marginal waters, such as brackish waters or domestic sewage treated for irrigation. Since fresh drinking water demands are intensifying due to world population growth, wastewater and brackish water are being considered a valuable resource in agriculture. Thus, problems related to water shortages have increased interest in research related to safe and controlled wastewater application techniques (HAMILTON et al., 2007).

Planning less expensive and water efficient irrigation strategies, choosing suitable species, improving seedling quality and proper soil preparation techniques can enable successful restoration program of a semiarid environment, in which high quality water is scarce (CORTINA et al., 2011). Thus, the reuse of alternative sources of water for forest seedling production aiming the restoration of the degraded area of semiarid regions is a promising alternative, mainly for those species which are tolerant to mild environmental stresses. Species native to the Brazilian semiarid region have adapted to these water shortage conditions, such as Anadenanthera colubrina (Vell.) Brenan; Erythrina velutina (Willd.) and Aspidosperma pyrifolium (Mart.) (DANTAS et al., 2014). These native species can be used for a variety of purposes, such as urban landscaping, pharmaceutical and medicinal applications (AGRA et al., 2007) and mainly the recovery ad restoration of the Caatinga vegetation (RIBEIRO-FILHO; FUNCH; RODAL, 2009).

Twenty percent of the worldwide total cultivated, representing more than $6 \%$ of the world's land and 33\% of irrigated agricultural lands are afflicted by high salinity; and that these salinized areas are increasing at a rate of $10 \%$ annually (SHRIVASTAVA; KUMAR, 2015). Thus, it is predicted that more than $50 \%$ of cropping land would be salinized by the year 2050 (JAMIL et al., 2011). It is estimated that about 4.5 million hectares in Brazil are affected by the concentrated salinization, especially in the semiarid northeast. The species Anadenanthera colubrina, Erythrina velutina and Aspidosperma pyrifolium could also be an important alternative for both the use and revitalization areas in a salinization process or of already salinized areas (HOLANDA et al., 2011). Once salt-affected soils can be used to grow salt-tolerant species, the expansion of areas where the revitalization processes are economically and logistically limited will be possible.

Biosaline agriculture is described as agriculture techniques using salinized soils, seawater, brackish groundwater $(\mathrm{BGW})$ or wastewater, to grow salt tolerant glycophyte or 
halophyte (MASTERS; BENES; NORMAN, 2007). In line with this approach, various studies have attempted to evaluate the efficiency and safety of water reuse, mainly in countries or regions where potable water is limited and available groundwater is brackish. This is the case in the Caatinga ecosystem, where BGW can be used for irrigation in non-saline soils, or in sodic soils in tolerant crops or native vegetation (DANTAS et al., 2014; SOUSA et al., 2009).

An environment with a high salt content can lead to water loss from cells and a decrease in turgor pressure. Tolerance to salinity is not an inherent attribute, rather the result of various features that depend on different physiological interactions that are difficult to determine. At the same time, the accumulation of specific ions inside the plant, such as sodium and chloride, can interfere directly with internal biochemical processes (MASTERS; BENES; NORMAN, 2007). Excessive soil salinity is one of the main factors that prevent plants from spreading in their natural habitats. Germination and the initial growth of seedlings are the most sensitive developmental stages to water availability and salinity; the extent of the sensitivity depends on the salt tolerance of the parent plant (RAJENDRAN et al., 2009). Therefore, the successful establishment of a species in the Caatinga region depends on both the adaptive aspects of seed germination and the early growth of seedlings. $\mathrm{NaCl}$ is the main salt that causes substrate salinization; as such, it is not surprising that plants have developed mechanisms in response to its accumulation (MUNNS; TESTER, 2008). In this sense, carrying out studies that take into consideration seed germination and seedling growth can minimize issues of water restriction and salinity, thereby supporting programs that contribute to the revitalization of degraded environments.

The use of BGW in fish farming has opened new opportunities for the semiarid environment (CAMPECHE et al., 2014). Wastewater from fish farming can be important as an alternative source of water, saving large amounts of water normally used for irrigation, which generally accounts for the highest water demands in dry regions. This biosaline water (BIOW) can be also a nutrient supply for plants as well as an important recycling system (TODERICH et al., 2008).

Brazilian Agricultural Research Corporation (Embrapa Semiarid) has developed an integrated production system with fish farming, making possible an environmental solution for the brine residue from reverse-osmosis desalination (PORTO et al., 2004), by adding it to fish tanks. The brackish water remaining from fish farming is usually used for irrigation of saltbush hay (Atriplex nummularia Lindl.), an halophyte forage species that has been used for ruminants' feeding (MORENO et al., 2015). In order to use this BIOW also to restore degraded environments and take advantage of local biodiversity in a sustainable way, it is imperative to determine whether native species have the economic potential and salinity tolerance required.

The purpose of this study was to evaluate the efficiency of irrigation with wastewater from tilapia farming and saline groundwater on the production of Anadenanthera colubrina, Erythrina velutina and Aspidosperma pyrifolium seedlings in forest nursery. Therefore, in this study, we tested the hypothesis that the seed emergence and the seedling growth would be mildly affected by irrigation with brackish water and that recycling brackish water used in fish farming can be an efficient use of wastewater in tree nurseries for restoration programs.

\section{Materials and methods}

\section{Seed harvest and initial characteristics}

Seeds of Anadenanthera colubrina, Aspidosperma pyrifolium and Erythrina velutina were harvested, from September to November 2013, in Jutaí, Pernambuco state, Brazil $\left(08^{\circ} 34^{\prime} 3^{\prime \prime}\right.$, $40^{\circ} 09^{\prime} 46^{\prime} \mathrm{W}$ ) from at least 10 mother plants, 100 to $500 \mathrm{~m}$ apart, in the same populations. After the harvest, the fruits were sun-dried and manually processed by removing all impurities, such as fruit remains, small branches and unfilled seeds. After that, the processing seeds were assessed 
for their initial characteristics, such as weight, water content and germination (BRASIL, 2009) and stored in cotton fabric bags in a controlled environment $\left(10^{\circ} \mathrm{C}\right.$ and $\left.50-60 \% \mathrm{RH}\right)$ during approximately five months before starting trials.

\section{Seedling production}

The experiment had a completely randomized design with three irrigation water sources (tap water and two sources of brackish water) and four replications with five seedlings. Some variables, which will be described, were evaluated in several different dates, providing a factorial scheme (irrigation water source $\mathrm{x}$ time).

Two seeds were sowed in each $2 \mathrm{dm}^{-3}$ polyethylene bags, filled with a 1:1 proportion (v/v) of thin sand and Caatinga soil. No fertilization of soil was performed to avoid masking effects of treatments. Seeds of Erythrina velutina have a hard and impermeable tegument and were scarified with a mini grinding saw prior to sowing (REIS et al., 2012).

Bags containing seeds and seedlings were daily irrigated, and freely drained, at the waterholding capacity, with tap water (TW), biosaline water (BIOW) or brackish groundwater (BGW). The BGW was collected from artesian wells in the Caatinga Experimental Area of Embrapa Semiarid, Petrolina, Pernambuco state, Brazil (904'08.9'S $40^{\circ} 19^{\prime} 36.1^{\prime \prime} W$; Figure 1) and the BIOW was collected from tilapia (Oreochromis sp.) farming tanks, at the same location, supplied with concentrated brine from brackish water desalination (PORTO et al., 2004).

Samples of the water used were analyzed for chemical and physical characteristics (Table 1), which were: electrical conductivity - EC $\left(\mathrm{dS} \mathrm{m}^{1}\right)$; potential hydrogen $-\mathrm{pH}$; calcium - $\mathrm{Ca}^{2+}$ $\left(\mathrm{mmol}_{\mathrm{o}} \mathrm{L}^{-1}\right)$; magnesium $-\mathrm{Mg}^{2+}\left(\mathrm{mmol}_{\mathrm{o}} \mathrm{L}^{-1}\right)$; sodium $-\mathrm{Na}^{+}\left(\mathrm{mmol}_{\mathrm{o}} \mathrm{L}^{-1}\right)$; potassium $-\mathrm{K}^{+}\left(\mathrm{mmol}_{\mathrm{o}} \mathrm{L}^{-1}\right)$; carbonates $-\mathrm{CO}_{3}{ }^{2-}\left(\mathrm{mmol}_{\mathrm{o}} \mathrm{L}^{-1}\right)$; bicarbonates $-\mathrm{HCO}^{3-}\left(\mathrm{mmol}_{\mathrm{o}} \mathrm{L}^{-1}\right)$; sulfates $-\mathrm{SO}_{4}^{2-}\left(\mathrm{mmol}_{\mathrm{o}}^{\circ} \mathrm{L}^{-1}\right)$; chlorides - $\mathrm{Cl}^{-}\left(\mathrm{mmol}_{\mathrm{o}} \mathrm{L}^{-1}\right)$; total dissolved ions - TDI $\left(\mathrm{mg} \mathrm{L}^{-1}\right)$ and sodium absorption rate- SAR (TEDESCO, 1995).

The nursery was also located at Caatinga Experimental Area of Embrapa Semiarid, Petrolina, Pernambuco state, Brazil (9 $9^{\circ} 04^{\prime} 08.9^{\prime \prime}$ S $40^{\circ} 19^{\prime} 36.1^{\prime \prime W}$; Figure 1) and the seedlings were grown between 23/03/2017 and 11/06/2017 in a shaded screen. Environmental climate data during trial were collected from a meteorological station at the site (Figure 1).

Table 1 - Brackish groundwater, biosaline water and tap water chemical characteristics.

Tabela 1 - Características químicas da água salobra subterrânea, água biossalina e água de abastecimento.

\begin{tabular}{|c|c|c|c|c|}
\hline Characteristics & Unit & $\mathrm{BGW}^{*}$ & BIOW & TW \\
\hline Electric conductivity $(\mathrm{EC})$ & $\mathrm{dS} \mathrm{m}^{-1}$ & 6.3 & 6.8 & 0.1 \\
\hline pH & & 8.1 & 7.2 & 3.9 \\
\hline \multicolumn{5}{|l|}{ Cations } \\
\hline Calcium $\left(\mathrm{Ca}^{2+}\right)$ & $\mathrm{mmol}_{\mathrm{o}} \mathrm{L}^{-1}$ & 8.81 & 0.40 & 0.48 \\
\hline Magnesium $\left(\mathbf{M g}^{2+}\right)$ & $\mathrm{mmol}_{\mathrm{o}} \mathrm{L}^{-1}$ & 4.90 & 2.06 & 1.64 \\
\hline Sodium $\left(\mathbf{N a}^{+}\right)$ & $\operatorname{mmol}_{0}^{0} L^{-1}$ & 14.40 & 0.36 & 0.13 \\
\hline $\operatorname{Potassium}\left(\mathbf{K}^{+}\right)$ & $\mathrm{mmol}_{\mathrm{o}}^{\mathrm{L}} \mathrm{L}^{-1}$ & 0.72 & 0.13 & 0.1 \\
\hline \multicolumn{5}{|l|}{ Anions } \\
\hline Carbonates $\left(\mathrm{CO}_{3}{ }^{2-}\right)$ & $\mathrm{mmol}_{\mathrm{o}} \mathrm{L}^{-1}$ & 0.11 & 0 & 0 \\
\hline Bicarbonates $\left(\mathrm{HCO}^{3-}\right)$ & $\mathrm{mmol}_{\mathrm{o}} \mathrm{L}^{-1}$ & 2.94 & 0.58 & 0.81 \\
\hline Sulfates $\left(\mathrm{SO}_{4}{ }^{2-}\right)$ & $\mathrm{mmol}_{\mathrm{o}} \mathrm{L}^{-1}$ & 4.31 & 1.60 & 0.78 \\
\hline Chlorides $\left(\mathrm{Cl}^{-}\right)$ & $\mathrm{mmol}_{\mathrm{o}}^{\mathrm{L}} \mathrm{L}^{-1}$ & 17.20 & 0.85 & 0.4 \\
\hline Total dissolved ions & $\mathrm{mg} \mathrm{L}^{-1}$ & 2045 & 299 & 205 \\
\hline Sodium adsortion ratio & & 3.5 & 0.21 & 0.08 \\
\hline
\end{tabular}

Where: $* \mathrm{BGW}=$ brackish groundwater, $\mathrm{BIOW}=$ biosaline water, $\mathrm{TW}=$ tap water. 


\section{Figure 1 - Climate data during trial (23/03/2017 to 11/06/2017) at Caatinga Experimental Field, Embrapa Semiarid, Petrolina, Pernambuco state, Brazil.}

Figura 1 - Dados climáticos durante o experimento (23/03/2017 a 11/06/2017) no Campo Experimental da Caatinga, Embrapa Semiárido, Petrolina - PE, Brasil.

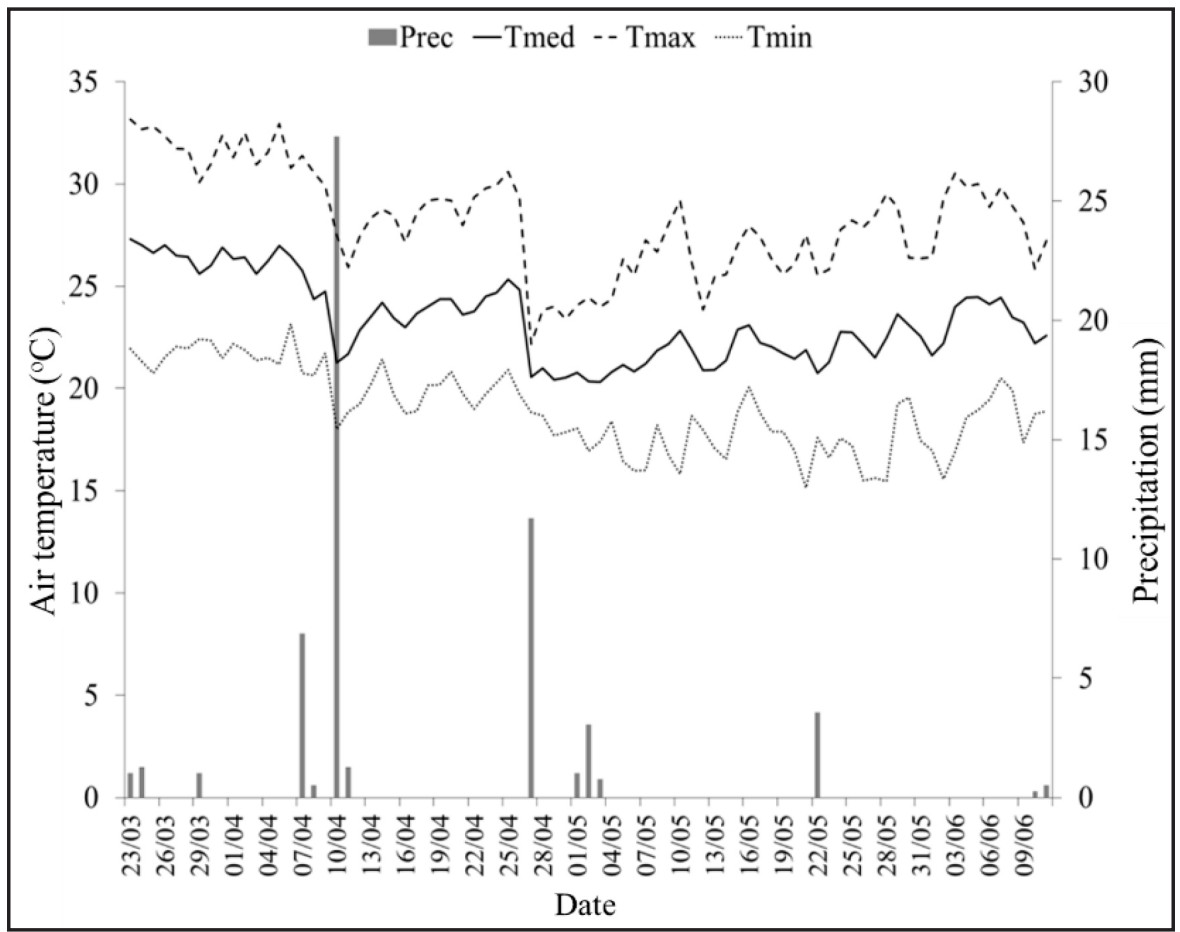

Source: Labmet, Embrapa Semiarid, 2019 (https:/www.embrapa.br/semiarido/ laboratorios/agrometeorologia)

Fonte: Labmet, Embrapa Semiárido, 2019 (https:/www.embrapa.br/semiarido/ laboratorios/agrometeorologia)

\section{Seedlings emergence and growth}

Seedling emergence (cotyledons emerged from soil) was daily evaluated. When no seedling emerged in five consecutive days, both the final emergence percentage $(\% \mathrm{E})$ and emergence speed index (ESI) were calculated (MAGUIRE, 1962). Nondestructive evaluations, such as plant height $(\mathrm{PH})$ and number of leaves (NL), were evaluated weekly until 80 days after sowing.

Also due to differences in seedlings emergence and growth characteristics, the destructive evaluations of seedlings development of Anadenanthera colubrina were performed after 17 and 66 days from sowing; Aspidosperma pyrifolium seedling were evaluated after 45, 59, 73 and Erythrina velutina after 45, 59, 73 and 80 days from sowing. Shoot length (SL), primary root length (RL), dry shoot mass (SDM), dry root mass (RDM) and seedling water contents (WC) were evaluated for all species. Plant fresh and dry mass was determined by the average weight of five plants for each replicate and after 72 hours at $70^{\circ} \mathrm{C}$ dry mass was weighed. Along with the total of seedlings (shoot + root) and the fresh and dry mass, the water content (\%) was obtained by the following equation:

$$
\text { Water content }=\frac{\text { total fresh mass-total dry mass }}{\text { total fresh mass }} * 100
$$




\section{Statistical analysis}

The distribution of the data was normal according to Shapiro-Wilk test and Leven's test showed homogeneity of variances. Thus data was were analyzed by ANOVA and F test, at $5 \%$ probability and differences between the obtained averages were compared by the Tukey's test at 5\% probability, using the statistical program Assistat (SILVA, FAS; AZEVEDO, 2016). The confidence intervals were also calculated and presented in graphs.

\section{Results and discussion}

\section{Emergence and seedling growth}

The seeds used in this trial presented potential germination around $100 \%$ and water content ranging from $7.35 \%$ and $12.85 \%$, which was adequate for each species studied. Final seedlings emergence percentage and emergence speed index, showed significant difference in response to irrigation water source for all the three species evaluated (Table 2).

Table 2 - Characteristics of seeds of Anadenanthera colubrina, Aspidosperma pyrifolium and Erythrina velutina after processing.

Tabela 2 - Características das sementes de Anadenanthera colubrina, Aspidosperma pyrifolium e Erythrina velutina após beneficiamento.

\begin{tabular}{cccc}
\hline Specie & Weight $\left(\mathbf{m g . s e e d}^{-1}\right)$ & Water content $(\%)$ & Germination $(\%)$ \\
\hline Anadenanthera colubrina & 130.49 & 12.85 & 100.00 \\
Aspidosperma pyrifolium & 1.18 & 8.82 & 98.00 \\
Erythrina velutina & 540.27 & 7.35 & 100.00 \\
\hline
\end{tabular}

All characteristics evaluated were affected by irrigation water source and age of seedlings, with an exception for shoot length and overall root development for Anadenanthera colubrina seedlings which were not affected by the irrigation water. For this species, the water source and age of seedlings were independent. On the other hand, the seedling characteristics showed some interactions between the seedling age and the water source for Aspidosperma pyrifolium and Erythrina velutina (Table 3).

Emergence of Anadenanthera colubrina seedlings irrigated with BIOW was higher than $50 \%$ and did not differ from TW irrigated seedlings. Seedlings of Aspidosperma pyrifolium showed the highest emergence percentage $(>61 \%)$ also when irrigated with BIOW (Figure $2 \mathrm{~A}$ ). Seedlings of both Anadenanthera colubrina and Aspidosperma pyrifolium showed lower emergence percentage when irrigated $B G W$ by confidence intervals and the mean comparison test (Figure 2A). On the other hand, Erythrina velutina seedlings showed an opposite response to irrigation water source. Seedlings emergence was the highest in TW and the lowest in BIOW, although all treatments allowed the emergence of more than $90 \%$ of seedlings (Figure 2A). 
Table 3 - Summary of the analysis of variance, by mean square referring to seedlings emergence and growth of Anadenanthera colubrina, Aspidosperma pyrifolium and Erythrina velutina irrigated with brackish groundwater, biosaline water and tap water.

Tabela 3 - Resumo da análise de variância com quadrados médios referindo-se à emergência e crescimento de mudas de Anadenanthera colubrina, Aspidosperma pyrifolium and Erythrina velutina irrigadas com água salobra subterrânea, água biossalina e água de abastecimento.

\begin{tabular}{|c|c|c|c|c|}
\hline \multirow[t]{2}{*}{ Source of variation } & \multicolumn{3}{|c|}{ 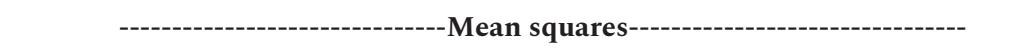 } & \multirow[t]{2}{*}{$\mathrm{CV} \%$} \\
\hline & Days after sowing $(D)$ & Irrigation water source $(\mathbf{W})$ & $\mathbf{D}^{*} \mathbf{W}$ & \\
\hline \multicolumn{5}{|c|}{ Anadenanthera colubrine } \\
\hline $\mathbf{E} \%$ & - & $585.204^{*}$ & - & 25.5 \\
\hline ESI & - & 0.020 * & - & 27.83 \\
\hline PH & $90.102^{\star *}$ & $232.751^{\star *}$ & $18.0344^{\mathrm{ns}}$ & 36.22 \\
\hline NL & $1949.794^{\star *}$ & $3197.076^{* *}$ & $526.057^{\mathrm{ns}}$ & 40.62 \\
\hline SL & $44.417^{* *}$ & $0.728^{\mathrm{ns}}$ & $14.250^{\mathrm{ns}}$ & 20.49 \\
\hline RL & $993.306^{* *}$ & $6.430^{\mathrm{ns}}$ & $4.003^{\mathrm{ns}}$ & 8.41 \\
\hline SDW & $1.392^{\star *}$ & $0.093^{*}$ & $0.063^{\text {ns }}$ & 28.57 \\
\hline RDW & $13.024^{\star *}$ & $0.717^{\mathrm{ns}}$ & $0.462^{\mathrm{ns}}$ & 44.97 \\
\hline WC & $1317.498^{\star \star}$ & $62.924^{* *}$ & $33.680^{\star \star}$ & 3.13 \\
\hline \multicolumn{5}{|c|}{ Aspidosperma pyrifolium } \\
\hline $\mathbf{E} \%$ & - & $1111.556^{\star *}$ & - & 24.74 \\
\hline ESI & - & $0.009^{*}$ & - & 29.86 \\
\hline PH & $24.527^{* *}$ & $26.527^{\star *}$ & $2.013^{\star \star}$ & 20.64 \\
\hline NL & $11.719^{* *}$ & $6.867^{* *}$ & $0.696^{* *}$ & 29.07 \\
\hline SL & $5.838^{* \star}$ & $3.373^{* *}$ & $0.602^{\mathrm{ns}}$ & 11.50 \\
\hline RL & $90.559^{* *}$ & $21.202^{\star *}$ & $23.150^{\star *}$ & 10.16 \\
\hline SDW & $3.446^{* *}$ & $0.686^{* *}$ & $0.115^{* *}$ & 16.98 \\
\hline RDW & $0.536^{* *}$ & $0.151^{* *}$ & $0.015^{*}$ & 17.79 \\
\hline WC & $200.039^{* *}$ & $149.858^{\star *}$ & $2.809^{\text {ns }}$ & 1.48 \\
\hline \multicolumn{5}{|c|}{ Erythrina velutina } \\
\hline $\mathbf{E} \%$ & - & $47.853^{* *}$ & - & 4.93 \\
\hline ESI & - & $0.472^{* *}$ & - & 9.28 \\
\hline PH & $10.924^{* *}$ & $114.293^{* *}$ & $1.3087^{\mathrm{ns}}$ & 30.49 \\
\hline NL & $238.5649^{\star \star}$ & $1561.886^{* *}$ & $33.378^{\mathrm{ns}}$ & 41.09 \\
\hline SL & $11.5954^{\star *}$ & $77.838^{\star *}$ & $1.368^{\mathrm{ns}}$ & 9.36 \\
\hline RL & $114.9906^{* *}$ & $33.486^{* *}$ & $12.793^{\mathrm{ns}}$ & 15.71 \\
\hline SDW & $49.5827^{\text {** }}$ & $10.077^{\star *}$ & $1.838^{* *}$ & 18.14 \\
\hline RDW & $1.2431^{* *}$ & $0.945^{* *}$ & $0.162^{* *}$ & 17.79 \\
\hline WC & $161.677^{\star \star}$ & $2.225^{\mathrm{ns}}$ & $4.773^{\mathrm{ns}}$ & 1.98 \\
\hline
\end{tabular}

Where: $\mathrm{ns} ;{ }^{*} ;{ }^{* *}=$ non significant, significant at $10 \%$ and $1 \%$, respectively. $\mathrm{E} \%=$ final emergence percentage, $\mathrm{ESI}=$ emergence speed index, $\mathrm{PH}=$ plant height, $\mathrm{NL}=$ number of leaves, $\mathrm{SL}=$ shoot length, $\mathrm{RL}=$ root length, $\mathrm{SDM}=$ shoot dry mass, RDM = root dry mass, $\mathrm{WC}=$ water content of seedlings. 
Irrigation water source had little effect on emergence speed index of Erythrina velutina which emerged much faster than the other two studied species. Emergence speed was also lower in BGW irrigated seedlings in all species studied, while TW and BIOW irrigated seedlings showed similar speed (Figure 2B).

Figure 2 - Emergence percentage (A) and emergence speed index - ESI (B) of Anadenanthera colubrina (black bars), Aspidosperma pyrifolium (grey bars) and Erythrina velutina (hatched

bars) seedlings irrigated with tap water (TW), biosaline water (BIOW) and brackish groundwater (BGW). Confidence intervals are represented by vertical bars, and same capital letters for Anadenanthera colubrina, lower case letters for Aspidosperma pyrifolium and greek letters for Erythrina velutina, show similar results by Tukey test $(\mathbf{p}<0.05)$.

Figura 2 - Porcentagem de emergência (A) e índice de velocidade de emergência - ESI (B) das mudas de Anadenanthera colubrina (barras pretas), Aspidosperma pyrifolium (barras cinza) e Erythrina velutina (barras hachuradas) irrigadas com água de abastecimento (TW), água biossalina (BIOW) e água salobra subterrânea (BGW). Intervalos de confiança estão representados por barras verticais e mesmas letras maiúsculas para Anadenanthera colubrina, minúsculas para Aspidosperma pyrifolium e letras gregas para Erythrina velutina, apresentam resultados similares pelo teste de Tukey $(\mathrm{p}<0.05)$.

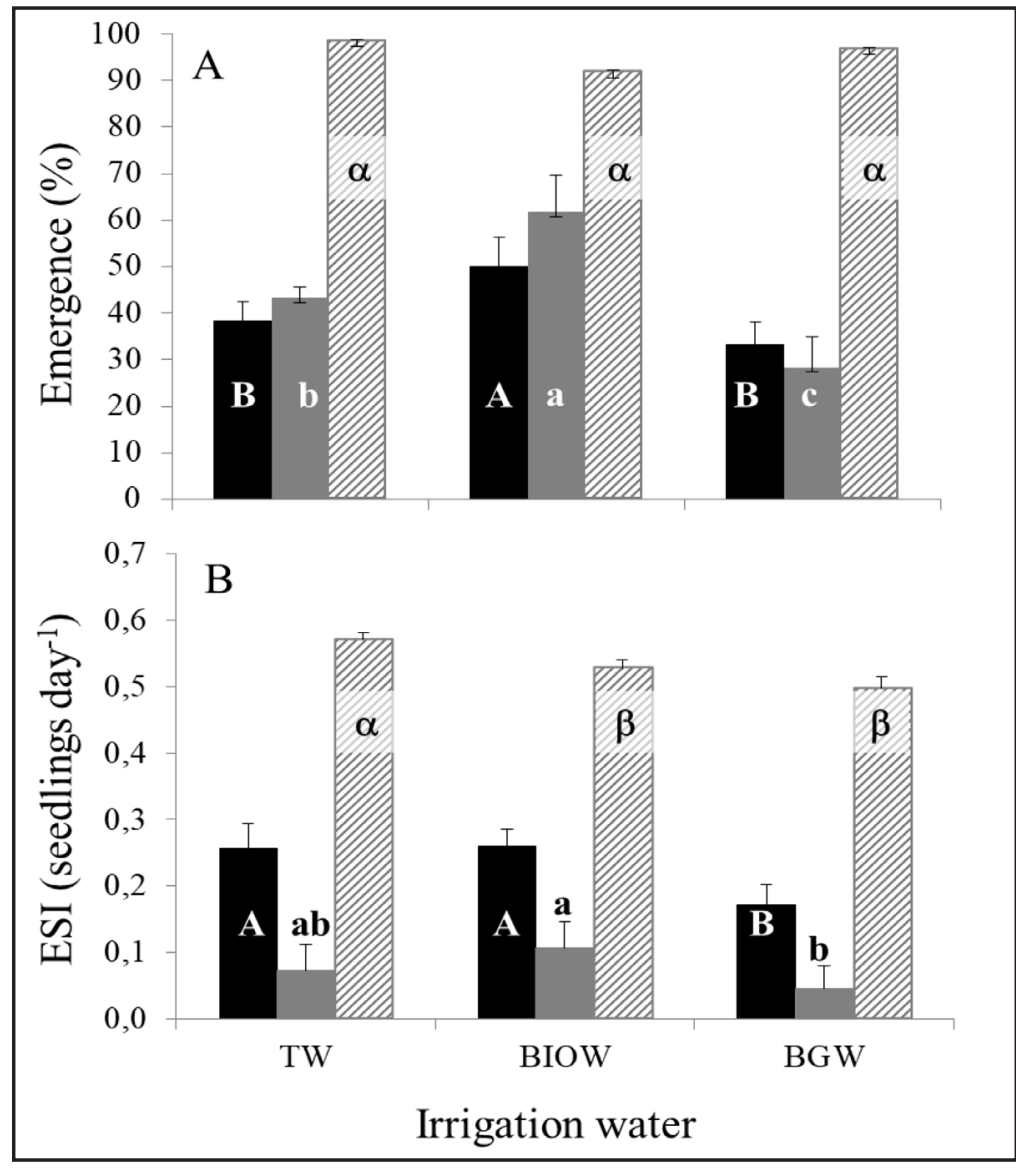

Source: B.F. Dantas (2019)

Fonte: B.F. Dantas (2019) 
All seedling growth variables showed differences among the evaluation dates for the three species evaluated. The irrigation water source influenced all the seedling growth variables of Aspidosperma pyrifolium and Erythrina velutina, however in Anadenanthera colubrina seedlings only plant height, number of leaves, and shoot and root dry weight were affected by irrigation water source (Table 2, Figures 4-10).

Figure 3 - Weekly plant height (A, C, E) and number of leaves (B, D, F) of Anadenanthera colubrina (A,B), Aspidosperma pyrifolium $(\mathrm{C}, \mathrm{D})$ and Erythrina velutina $(\mathrm{E}, \mathrm{F})$ seedlings irrigated with brackish groundwater (BGW), biosaline water (BIOW) and tap water (TW). When regression curves were not adjusted, confidence intervals are represented by vertical bars, and show similar results of means comparison Tukey test $(\mathbf{p}<0.05)$.

Figura 3 - Altura de plantas (A, C, E) e número de folhas (B, D, F) semanais das mudas de Anadenanthera colubrina (A, B), Aspidosperma pyrifolium (C, D) e Erythrina velutina (E, F) colubrina irrigadas com água de abastecimento (TW), água biossalina (BIOW) e água salobra subterrânea

(BGW). Quando as curvas de regressão não se ajustaram, os intervalos de confiança são representados por barras verticais e apresentam resultados similares ao teste de Tukey $(\mathrm{p}<0.05)$ para comparação de médias.

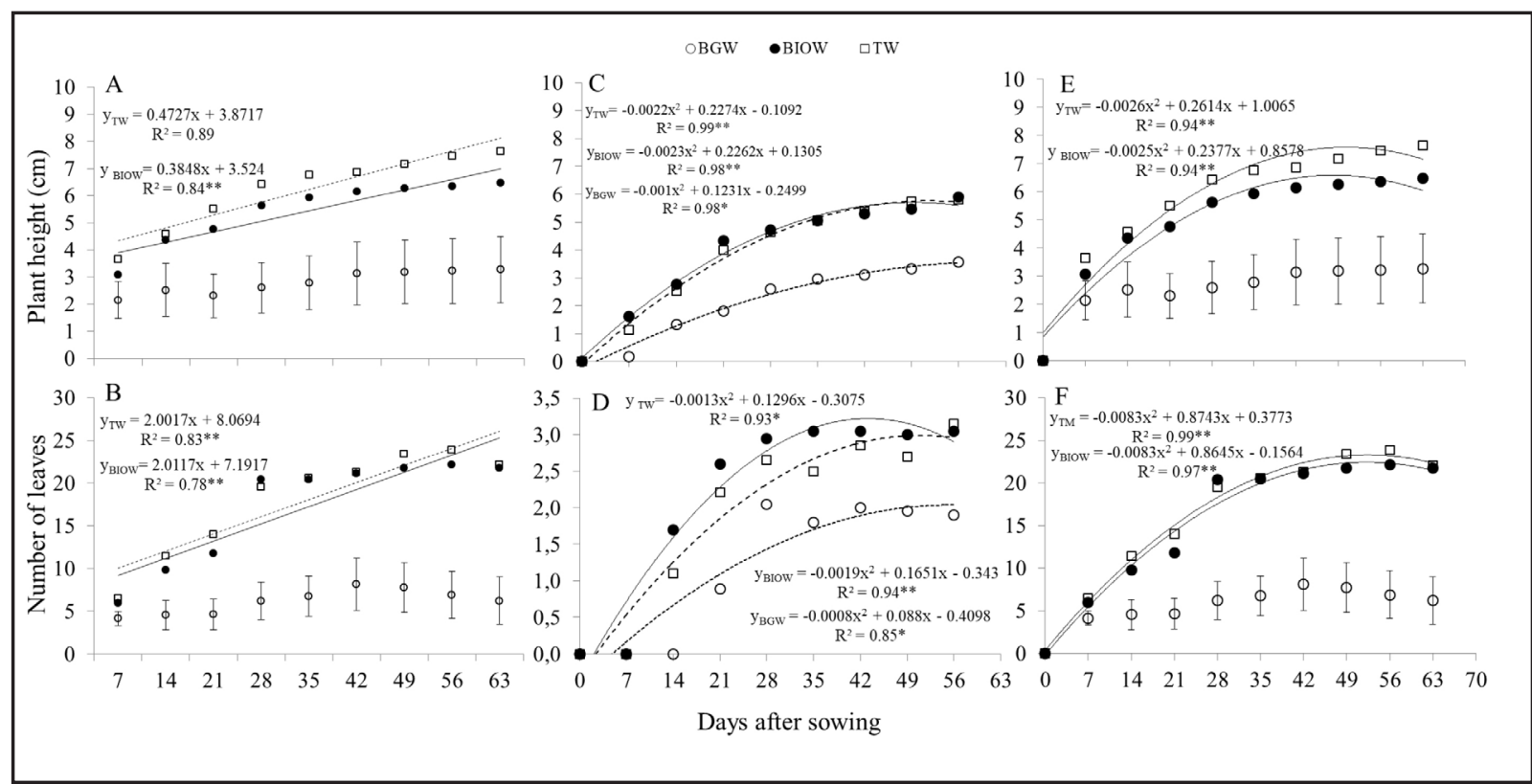

Source: B.F. Dantas (2019)

Fonte: B.F. Dantas (2019)

Weekly growth was similar in all seedlings irrigated with BIOW or TW (Figure 3). The weekly plant height and number of leaves of these seedlings irrigated with BGW were lower when compared with those irrigated with other waters (Figure 3). Seedlings of Anadenanthera colubrina and Erythrina velutina showed little or no growth from the first to last evaluation date (Figure 3A, B, E, F), whilst seedlings of Aspidosperma pyrifolium grew, although slower, even when irrigated with BGW (Figure 3C, D).

Due to growth characteristics, ideal stage for transplant, and the number of seedlings available, the three species studied in this work were evaluated for growth (shoot and root length and dry weight) in different days after sowing (Figures 4-6).

Seedlings of Anadenanthera colubrina, either with 17 or 66 days, showed no response to irrigation water source, regarding growth in shoot and root length (Figure 4A, B). On the other 
hand, growth in dry mass was higher in BIOW irrigated seedlings (Figure 4C, D). Shoot length showed a very small growth in the time span between the two evaluations (Figure 4A), however main root length increased more than 3 -fold in despite of the irrigation water source used (Figure 4B). Seedlings irrigated with BIOW, showed higher increase in dry weight of shoots ( $>4$-fold) and roots (> 12-fold) of Anadenanthera colubrina (Figure 4 C, D).

In all three evaluations, at 45, 59,73 days, Aspidosperma pyrifolium grew slowly in shoot and root length (Figure 5A, B), but biomass was continuously increased regardless of the irrigation water source (Figure 5C, D). BIOW irrigated seedlings usually showed similar or higher growth than those irrigated with TW and always higher growth, in length or weight, than BGW irrigated seedlings (Figure 5).

In Erythrina velutina seedlings up to 73 days after sowing, shoot length and dry weight of BIOW irrigated seedlings was always similar to TW and higher than BGW irrigated seedlings (Figure 6A, C).

Water content of young (17 days) Anadenanthera colubrina seedlings and throughout Aspidosperma pyrifolium seedling developments was higher when these ones were irrigated with BGW than with TW (Figure 7A, B), but similar in all developmental stages of Erythrina velutina seedlings (Figure 7C).

Figure 4 - Growth of Anadenanthera colubrina seedlings irrigated with brackish groundwater (BGW), biosaline water (BIOW) and tap water (TW). Shoot length (A); root length $(B)$; shoot dry weight $(C)$ and root dry weight $(D)$. Confidence intervals are represented by vertical bars, and same capital letters for irrigation water and lower case letters for evaluation date show similar results by Tukey test $(\mathbf{p}<0.05)$.

Figura 4 - Crescimento de mudas de Anadenanthera colubrina irrigadas com água subterrânea salobra (BGW), água biossalina (BIOW) e água de abastecimento (TW). Comprimento da parte aérea (A); comprimento da raiz principal (B); massa seca da parte aérea (C) e massa seca do sistema radicular (D). Intervalos de confiança estão representados por barras verticais e mesmas letras maiúsculas para água de irrigação e minúsculas para datas de avaliação apresentam resultados similares pelo teste de Tukey $(\mathrm{p}<0.05)$.

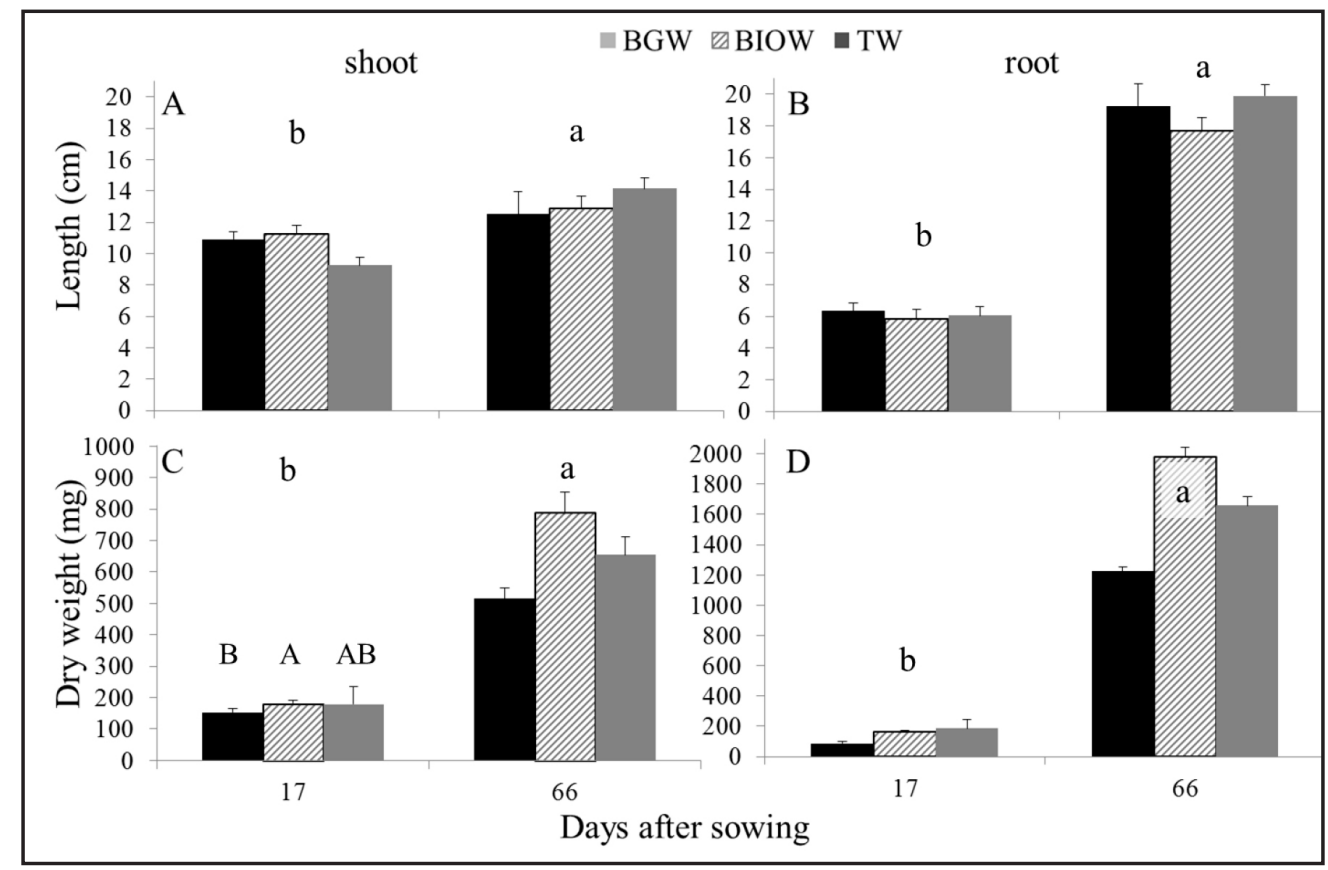

Source: B.F. Dantas (2019)

Fonte: B.F. Dantas (2019) 
Figure 5 - Shoot and root growth of Aspidosperma pyrifolium seedlings irrigated with brackish groundwater (BGW), biosaline water (BIOW) and tap water (TW). Shoot length (A); root length $(B)$; shoot dry weight $(C)$ and root dry weight $(D)$. Confidence intervals are represented by vertical bars, and same capital letters for irrigation water and lower case letters for evaluation date show similar results by Tukey test $(p<0.05)$.

Figura 5 - Crescimento de mudas de Aspidosperma pyrifolium irrigadas com água subterrânea salobra (BGW), água biossalina (BIOW) e água de abastecimento (TW). Comprimento da parte aérea (A); comprimento da raiz principal (B); massa seca da parte aérea (C) e massa seca do sistema radicular (D). Intervalos de confiança estão representados por barras verticais e mesmas letras maiúsculas para água de irrigação e minúsculas para datas de avaliação apresentam resultados similares pelo teste de Tukey $(\mathrm{p}<0.05)$.

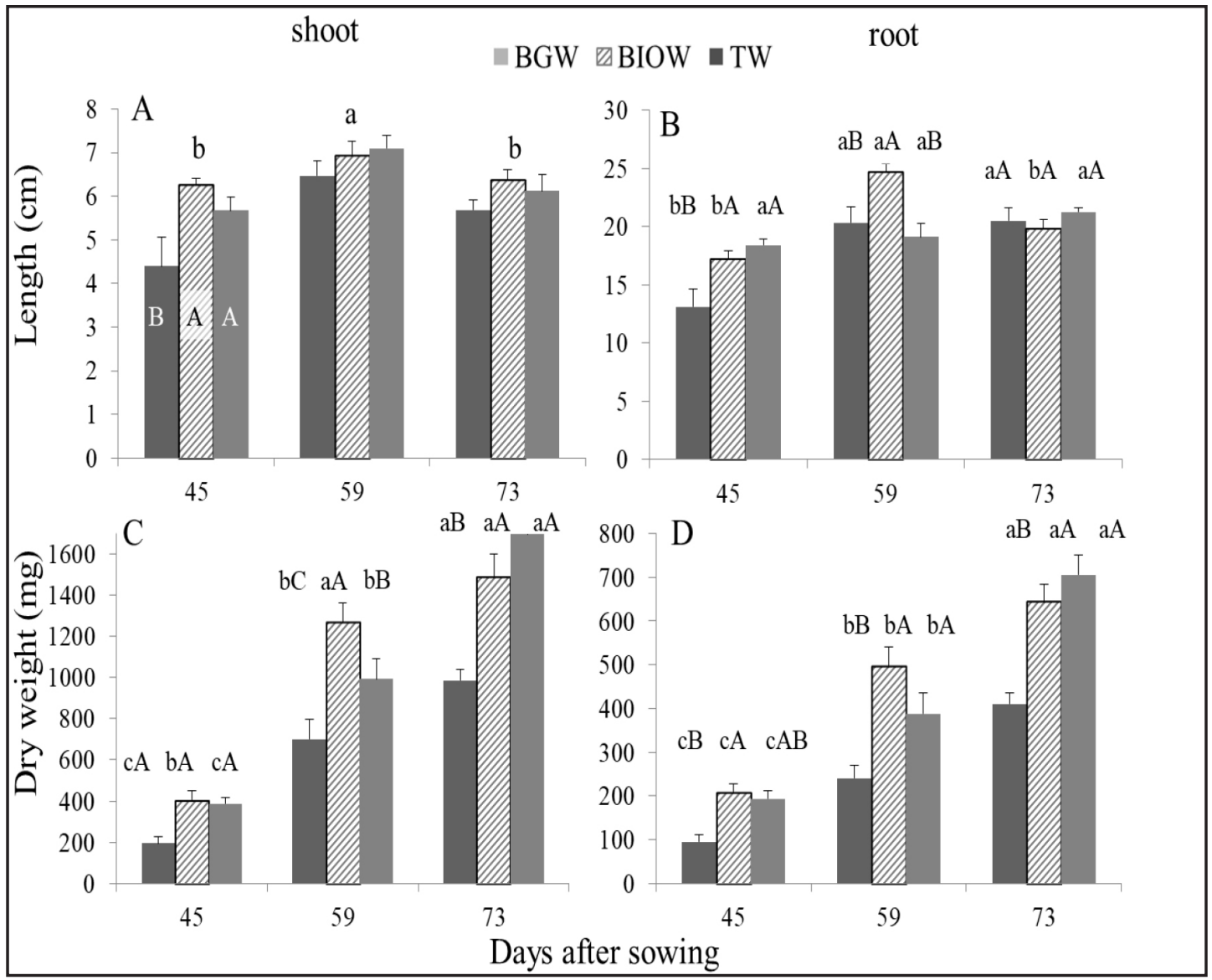

Source: B.F. Dantas (2019)

Fonte: B.F. Dantas (2019) 
Figure 6 - Shoot and root growth of Erythrina velutina seedlings irrigated with brackish groundwater $(B G W)$, biosaline water $(B I O W)$ and tap water (TW). Shoot length (A); root length $(B)$; shoot dry weight $(C)$ and root dry weight $(D)$. Confidence intervals are represented by vertical bars, and the same capital letters for irrigation water and lower case letters for the evaluation date show similar results by Tukey test $(\mathbf{p}<0.05)$.

Figura 6 - Crescimento de mudas de Erythrina velutina irrigadas com água subterrânea salobra (BGW), água biossalina (BIOW) e água de abastecimento (TW). Comprimento da parte aérea (A); comprimento da raiz principal (B); massa seca da parte aérea (C) e massa seca do sistema radicular (D). Intervalos de confiança estão representados por barras verticais e mesmas letras maiúsculas para água de irrigação e minúsculas para datas de avaliação apresentam resultados similares pelo teste de Tukey $(\mathrm{p}<0.05)$.

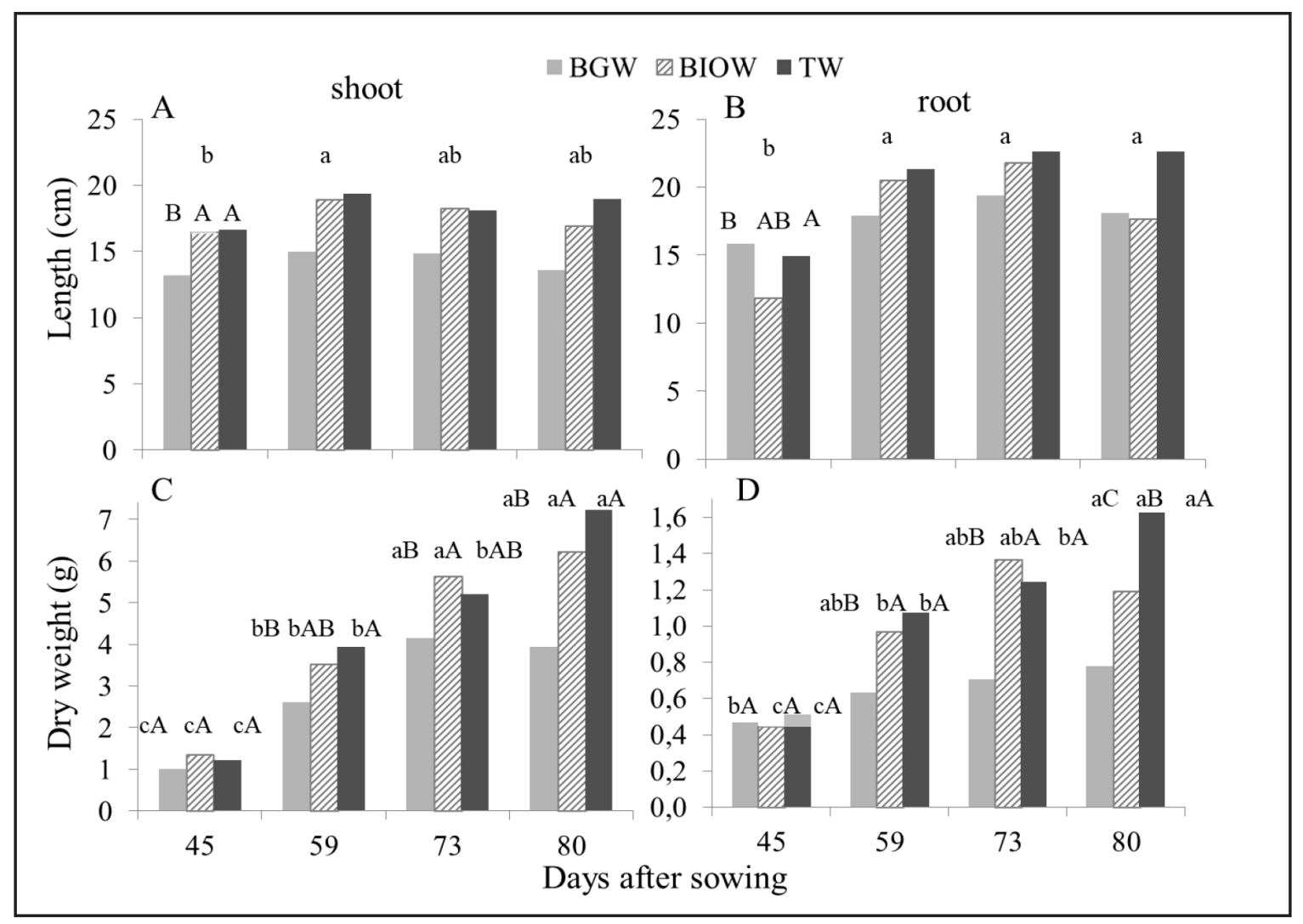

Source: B.F. Dantas (2019)

Fonte: B.F. Dantas (2019) 
Figure 7 - Water content (\%) during development of seedlings of Anadenanthera colubrina

(A), Aspidosperma pyrifolium (B); and Erythrina velutina (C) irrigated with brackish groundwater (BGW), biosaline water (BIOW) and tap water (TW). Confidence intervals are represented by vertical bars, and the same capital letters for irrigation water and lower case letters for evaluation date show similar results by Tukey test $(\mathbf{p}<0.05)$.

Figura 7 - Conteúdo de água (\%) durante o desenvolvimento de mudas de Anadenanthera colubrina (A), Aspidosperma pyrifolium (B); e Erythrina velutina (C) irrigada com água subterrânea salobra (BGW), água biossalina (BIOW) e água de abastecimento (TW). Intervalos de confiança estão representados por barras verticais mesmas letras maiúsculas para água de irrigação e minúsculas para datas de avaliação apresentam resultados similares pelo teste de Tukey $(\mathrm{p}<0.05)$.

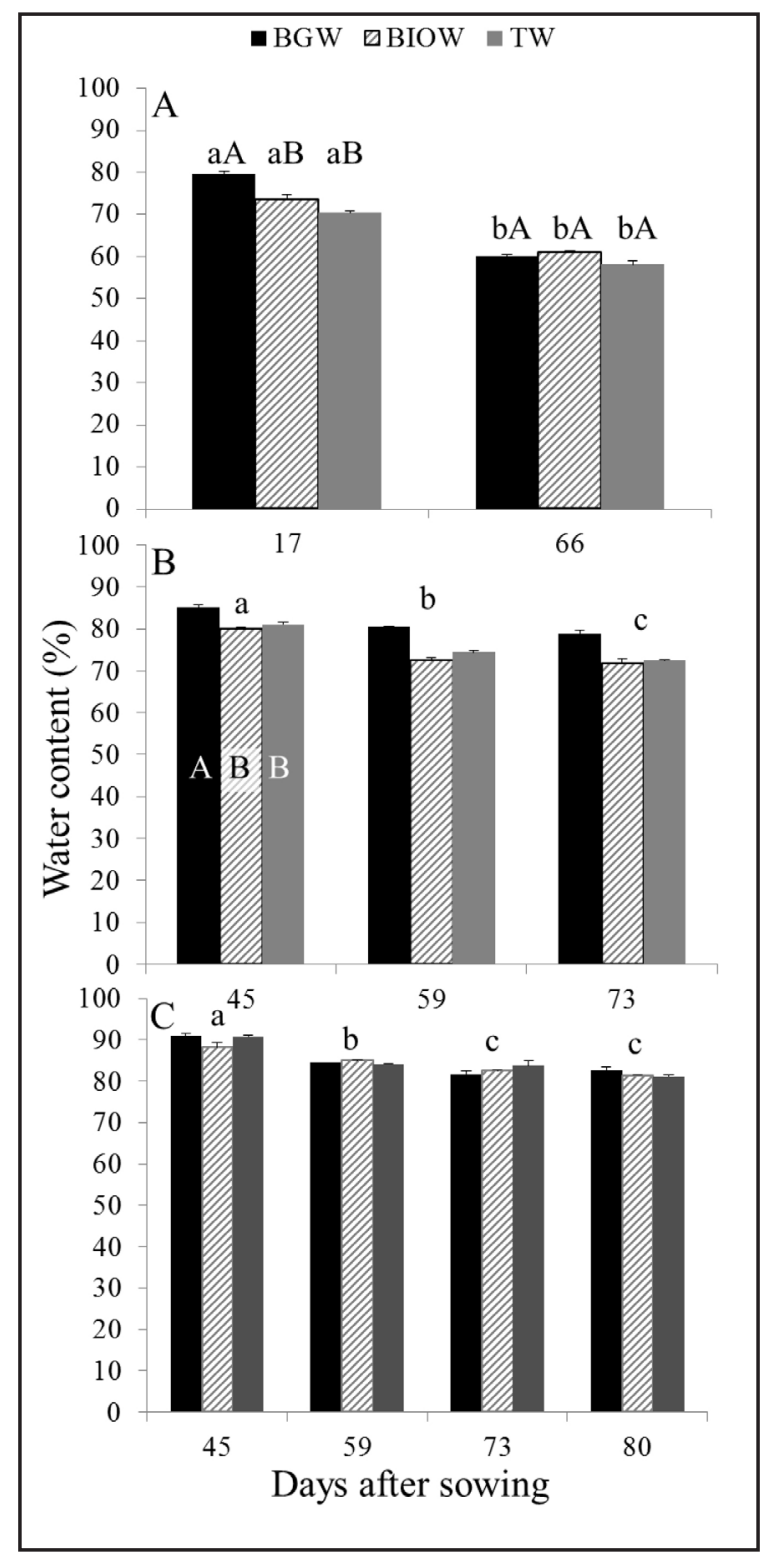

Source: B.F. Dantas (2019)

Fonte: B.F. Dantas (2019) 
Throughout the plant life cycle, the seeds exhibit the greatest resistance to highly stressful environments, whereas young seedlings are more susceptible. This is especially true for desert or semiarid species, such as the species studied in this work. Studies investigating the effect of biosaline water on the germination (in lab trials) of these three dryland specialist species, showed that the seeds are tolerant (ie germination around 100\%) to BGW with salinity levels of up to EC $=5 \mathrm{dS} \cdot \mathrm{m}^{-1}$ and that seedling growth under biosaline agriculture is viable (DANTAS et al., 2014). In nursery conditions, these information were confirmed by this work (Figures 3-7), in which seedlings emerged and developed even when irrigated with high electric conductivity BGW $\left(E C=6.8 \mathrm{dS} . \mathrm{m}^{-1}\right)$, even though in a slower rate. Furthermore, fish farming waste water (BIOW, EC $=6.2 \mathrm{dS} . \mathrm{m}^{-1}$ ), enhanced seedling development to a point in which seedlings had similar or higher development than those irrigated with TW (Figures 3-7).

The composition of salts in water varies according to the source and properties of the constituent chemical compounds. Thus, types of available non-potable water sources vary with regions or even locations (NIU; CABRERA, 2010). Variation of groundwater quality in an area is a function of physical and chemical parameters that are greatly influenced by geological formations and anthropogenic activities (RENGASAMY, 2006). In the semiarid region of Brazilian Northeast groundwater is brackish, $30 \%$ of its area is geologically formed by peculiar crystalline rocks, which upon weathering originated $\mathrm{EC}=4 \mathrm{dS} . \mathrm{m}^{-1}$ groundwater (SUDENE, 1980). This might increase up to EC $>6 \mathrm{dS} \cdot \mathrm{m}^{-1}$ (Table 1) due to lack of rain and agricultural bad practices (PORTO et al., 2006). The BGW and BIOW used in this study (EC $>6 \mathrm{dS} . \mathrm{m}^{-1}$, Table 1), is considered moderately saline (BELTRAN, 1999). Although both waters have similar EC, BGW showed more 10-fold content of total dissolved ions (TDI) and sodium adsorption ratio (SAR) than BIOW (Table 1). This is due to the influence of organic matter as well as nitrogen and potassium produced during the fish farming cycle, which can provide fertilization and enhance crop yield (ALMEIDA et al., 2017; MEDEIROS et al., 2013). The irrigation water source used in the experiment showed clear differences in chemical characteristics. The $\mathrm{pH}$ of the three irrigation water sources ranged from 3.9 to 8.1. Although both BIOW and BGW had EC $>6 \mathrm{dSm}^{-}$ ${ }^{1}$, BGW showed a much higher concentration of total dissolved ions (TDI) and sodium adsorption ratio (SAR), which were around ten-fold to BIOW. The BGW used for nursery plants irrigation presented much higher ion content than BIOW and TW. Sodium $\left(\mathrm{Na}^{+}\right)$and chloride $\left(\mathrm{Cl}^{-}\right)$are present in BGW in very high levels. TW showed low ion concentration and EC (Table 1).

Osmotic stress, which is a consequence of soil salinity, is usually immediate, and particularly harmful, to the seed germination, the seedling emergence and the young plant development. While the effects of specific ions are cumulative, their excess can disrupt the transpiration flow and eventually injure the leaves, thereby decreasing their growth (CHAVES et al., 2009; RAJENDRAN et al., 2009). In order to cope with these conditions, salt-tolerant plants can exclude salt from their roots, limit the amount of salt that is transferred to the meristem, move salt ions from the cytoplasm to the vacuoles, excrete excess salt from their leaves, or use a combination of these mechanisms (MASTERS; BENES; NORMAN, 2007). A decrease in biomass production under stress conditions is common in different species. Under salt stress, plants allocate small amounts of existing biomass to the development of the root system. The reason for this is that deep and vigorous roots extract water and nutrients from the soil more effectively (SILVA et al., 2009). The ability of protoplasm to tolerate high concentrations of salt depends on the osmotic balance between the cytoplasm and the different cellular compartments, such as the vacuole. This balance is maintained by the synthesis of organic compounds with osmotic activity, which results in the accumulation of amino acids, such as proline in seedlings (DANTAS et al., 2014). Maintaining appropriate water content in seedlings (Figure 10) can also be an important feature of tolerance to salt stress. A plant with a higher relative water fraction (the water content under stress conditions relative to control conditions) is better to maintain its water content in the shoot upon salt stress and, thus maintain photosynthetic machinery active (NEGRÃO; SCHMÖCKEL; TESTER, 2017). 
The effect of salinity differs throughout the plant, and depends on the species, the variety, and the phenological stage. Resistance or tolerance to salinity varies according to the species and its developmental stage. Seedlings of Cenostigma pyramidale (Tul.) Gagnon \& G.P. Lewis (syn. Poincianella pyramidalis (Tul.) L.P.Queiroz), a species from the Caatinga region which seedlings also show high salt-tolerance, were irrigated with BIOW with EC $=6.29 \mathrm{dS} \cdot \mathrm{m}^{-1}$, and showed a stem diameter growth similar to that observed with seedlings irrigated with TW (RIBEIRO et al., 2014). This species, along with those studied in this work suggest the possibility of forest seedling growth with reusable brackish water.

Determining the factors that alter survival and early development of seeds in the field, and the plant physiological characteristics that best relate to these variables, is problematic for nurserymen and producers of seedlings of forest species. The development of seeds that are more vigorous increases the chance of success when establishing a new species. It also maximizes the growth by decreasing the transplantation time to the field (HAASE, 2008). The broad range of these species distribution, and their growth in saline conditions (Figures 3-9) might allow them to become even more common in a global change scenario (FLORES; PÉREZ-SÁNCHEZ; JURADO, 2017).

\section{Conclusions}

Our study brings a new contribution to the knowledge and ongoing discussion of biosaline agriculture and its possible uses in plant production. Irrigation water source with conductivity levels of up to $\mathrm{EC}=6.78 \mathrm{dS} \cdot \mathrm{m}^{-1}$ does not compromise the initial growth of Anadenanthera colubrina, Aspidosperma pyrifolium and Erytrina velutina seedlings for up to 60 days, and therefore might be a possible alternative for the nursery emergence irrigation of these species in case of water shortage. Further works with seedlings survival in field may be necessary to confirm this statement.

\section{Acknowledgements}

We thank Daniela Ferraz Bacconi Campeche (Embrapa Semiárido) for providing fish farming wastewater and Tatiana Ayako Taura (Embrapa Semiárido) for providing map of collection sites. Funding was from Embrapa (Grant 02.11.01.007.00.03). Graduate scholarships were provided by Coordination for the Improvement of Higher Education Personnel (CAPES) and National Counsel of Technological and Scientific Development (CNPq).

\section{References}

AGRA, M. F. et al. Sinopse da Flora Medicinal do Cariri Paraibano. Oecologia Brasiliensis, Rio de Janeiro, v. 11, n. 3, p. 323-330, 2007.

ALMEIDA, J. P. N. et al. Production of Piptadenia stipulacea (Benth.) Ducke seedlings irrigated with fish farming wastewater. Revista Brasileira de Engenharia Agricola e Ambiental, Campina Grande, v. 21, n. 6, p. 386-391, 2017.

BELTRAN, J. M. Irrigation with saline water: benefits and environmental impact. Agricultural Water Management, Copenhaguen, v. 40, p. 183-194, 1999.

BRASIL. Regras para análise de sementes. Brasília: Mapa/ACS, 2009. 395 p.

CAMPECHE, D. F. B. et al. Tilapia production and feeding management in the semi-arid of Brazil: a view of some recent developed techniques. In: WAKEFIELD, R. (Org.). Tilapia: biology, management practices and human consumption. Documentos ed. Petrolina: Embrapa Semiárido, 2014. p. 89-101. 
CHAVES, M. M.; FLEXAS, J.; PINHEIRO, C. Photosynthesis under drought and salt stress: regulation mechanisms from whole plant to cell. Annals of Botany, Exeter, v. 103, n. 4, p. 551-60, fev. 2009.

CORTINA, J. et al. The restoration of vegetation cover in the semi-arid Iberian southeast. Journal of Arid Environments, Trelew, v. 75, n. 12, p. 1377-1384, 1 dez. 2011.

DANTAS, B. F. et al. Germinative metabolism of Caatinga forest species in biosaline agriculture. Journal of Seed Science, Londrina, v. 36, n. 2, p. 194-203, 2014.

FLORES, J.; PÉREZ-SÁNCHEZ, R.M.; JURADO, E. The combined effect of water stress and temperature on seed germination of Chihuahuan Desert species. Journal of Arid Environments, Trelew, v. 146, p. 95-98, 1 nov. 2017.

GUTIÉRREZ, A. P. A. et al. Drought preparedness in Brazil. Weather and Climate Extremes, Sydney, v. 3, p. 95-106, 2014.

HAASE, D. L. Understanding forest seedling quality: measurements and interpretation. Tree Planters' Notes, Washington, v. 52, n. 2, p. 24-30, 2008.

HAMILTON, A. J. et al. Wastewater Irrigation: The State of Play. Vadose Zone Journal, McLean, v. 6 , n. 4 , p. 823-840, nov. 2007.

HOLANDA, S. J. R. et al. Impacto da salinidade no desenvolvimento e crescimento de mudas de carnaúba (Copernicia prunifera (Miller) H. E. Moore). Revista Brasileira de Engenharia Agrícola e Ambiental, Campina Grande, v. 15, n. 1, p. 47-52, 2011.

IPCC. Climate Change 2013: The physical science basis. Working Group I Contribution to the Intergovernmental Panel on Climate Change Fifth Assessment Report. Cambridge, UK: Cambridge University Press, 2013.

JAMIL, A.et al. Gene expression profiling of plants under salt stress. Critical Reviews in Plant Sciences, Apopka, v. 30, n. 5, p. 435-458. 2011.

JANZEN, D. H. Tropical dry forests the most endangered major tropical ecosystem. In: WILSON, E. O.; PETER, F. M. (Eds.) Biodiversity. Washington : National Academies Press, 1988. p 130-137.

MAGUIRE, J. D. Speed of germination-aid in selection and evaluation for seedling emergence and vigor. Crop Science, Washington, v. 2, p. 176-177, 1962.

MAREngo, J. A. O futuro clima do Brasil. Revista USP, São Paulo, n. 103, p. 25, 2014.

MASTERS, D. G.; BENES, S. E.; NORMAN, H. C. Biosaline agriculture for forage and livestock production. Agriculture, Ecosystems and Environment, Budapest, v. 119, n. 3-4, p. 234-248, 2007.

MEDEIROS, D. C.; MARIA, C.; FAÇANHA, L. Qualidade de mudas de tomate em função do substrato e irrigação com efluente de piscicultura. Revista Brasileira de Agroecologia, Belém, v. 8, n. 2, p. 170-175, 2013.

MILES L. et al. A global overview of the conservation status of tropical dry forests. Journal of Biogeography, Zurich v. 33, n.2, p.491-505, 2006.

MORENO, G. M.B. et al. Meat quality of lambs fed different saltbush hay (Atriplex nummularia) levels. Italian Journal of Animal Science, Viterbo, v. 14, n. 2, p. 251-256, jan. 2015.

MUNNS, R.; TESTER, M. Mechanisms of Salinity Tolerance. Annual Review of Plant Biology, Davis, v. 59, n. 1, p. 651-681, jun. 2008.

NEGRÃO, S.; SCHMÖCKEL, S. M.; TESTER, M. Evaluating physiological responses of plants to salinity stress. Annals of Botany, Exeter, v. 119, n. 1, p. 1-11, 2017. 
NIU, G.; CABRERA, R. I. Growth and physiological responses of landscape plants to saline water irrigation: A review. HortScience, Alexandria, v. 45, n. 11, p. 1605-1609, 2010.

PORTO, E. R. et al. Rendimento da Atriplex nummularia irrigada com efluentes da criação de tilápia em rejeito da dessalinização de água. Revista Brasileira de Engenharia Agrícola e Ambiental, Campina Grande, v. 10, n. 1, p. 97-103, 2006.

PORTO, E. R. et al. Sistema de produção integrado usando efluentes da dessalinização. Documentos ed. Petrolina: Embrapa Semiárido, 2004. 22 p.

RAJENDRAN, K. TESTER, M.; ROY, S. J. Quantifying the three main components of salinity tolerance in cereals. Plant, Cell \& Environment, Medford, v. 32, n. 3, p. 237-249, 2009.

REIS, R. C. R.; DANTAS, B. F.; PELACANI, C. R. Mobilization of reserves and germination of seeds of Erythrina velutina Willd. (Leguminosae - Papilionoideae) under different osmotic potentials. Revista Brasileira de Sementes, Londrina, v. 34, n. 4, p. 580-588, 2012.

RENGASAMY, P. World salinization with emphasis on Australia. Journal of Experimental Botany, Oxford, v. 57, n. 5, p. 1017-1023, 2006.

RIBEIRO, R.C. et al. Germinação de sementes e produção de mudas de catingueira-verdadeira em água biossalina. Informativo ABRATES, Londrina, v. 24, n. 3, p. 50-54, 2014.

RIBEIRO-FILHO, A. A.; FUNCH, L.S.; RODAL, M. J. N.. Composição florísitica da floresta ciliar do rio Mandassaia, Parque Nacional da Chapada Diamantina, Bahia, Brasil. Rodriguésia, Rio de Janeiro, n. 2, p. 265-276, 2009.

SALAZAR, L. F.; NOBRE, C. A.; OYAMA, M.D. Climate change consequences on the biome distribution in tropical South America. Geophysical Research Letters, Washington, v. 34, n. 9, p. L09708, 2007.

SANTOS, S. A. et al. Aspectos da variabilidade sazonal da radiação, fluxos de energia e $\mathrm{CO}_{2}$ em área de Caatinga. Revista Brasileira de Geografia Física, Recife, v. 5, n. 4, p. 761-773, 2012.

SHRIVASTAVA, P.; KUMAR, R. Soil salinity: A serious environmental issue and plant growth promoting bacteria as one of the tools for its alleviation. Saudi Journal of Biological Sciences, Riyadh,v. 22, n. 2, p. 123-131, 2015.

SILVA, F. A. S.; AZEVEDO, C. A. V. The Assistat software version 7.7 and its use in the analysis of experimental data. African Journal of Agricultural Research, Cape Town, v. 11, n. 39, p. 3733-40, 2016.

SILVA, M. B. R. et al. Estresse salino em plantas da espécie florestal sabiá. Caminhos de Geografia, Uberlândia, v. 10, n. 30, 4 set. 2009.

SOUSA, R. B. C. et al. Seasonal variation of the groundwater for irrigation in Tibau microregion, Rio Grande do Norte State. Caatinga, Mossoró, v. 22, n. 4, p. 206-213, 2009.

SUDENE. Plano de aproveitamento integrado dos recursos hídricos do Nordeste do Brasil - fase I: recursos hídricos I águas subterrâneas. v. 7 ed. Recife: Departamento de Recursos Naturais, 1980.

TEDESCO, M. J. Análises de solo, plantas e outros materiais. 2. ed. Porto Alegre: Departamento de solos da UFRGS, 1995. 174 p.

TODERICH, K et al. Utilization of agriculture residues and livestock waste in Uzbekistan. Kier Discussion Paper Series, Kyoto, v. 651, 2008.

ZOMER, R. J. et al. Climate change mitigation: a spatial analysis of global land suitability for clean development mechanism afforestation and reforestation. Agriculture, Ecosystems and Environment, Budapest, v. 126, p. 67-80, 2008. 